\title{
Women Victims of Partition Imbroglio: Manto at his Best
}

\author{
Aju Mukhopadhyay \\ Poet, Critic and Author \\ India \\ ajum24@gmail.com
}

\begin{abstract}
Born in Ludhiana, Saadat Hasan Manto was opposed to his family tradition; aristocracy and study of Law. He grew up less educated, profligate, wayward and whimsical; smoking charas and other narcotics, drinking and gambling. Prone to frustration and dissipation he had no particular aim in life till he came to Bombay. Flowing through the stream of writing, mainly short stories, throughout his life he became a master story teller in Urdu. 'Manto's oeuvre' made him immortal writer of short stories in a short life span of less than 43 years. He left India for Pakistan and settled in his familiar town, Lahore, in 1948. His partition stories only have been discussed here. He never becomes partial in his dealing with woman. All his qualifications and disqualifications have been discussed here.
\end{abstract}

\section{Manto's stories were Intertwined with his Life}

Born on 11 May, 1912 in a village in Ludhiana, Punjab, India, Saadat Hasan Manto began a life in revolt against the aristocratic life style of his family members; differing with them in most aspects of life he grew up to be a less educated, profligate, wayward, whimsical teenager; smoking charas and other narcotics, drinking and gambling in the company of idlers. This continued throughout his life with occasional variations in the routine. To add variety to 
such negative qualities in him there grew up a magnetic attachment between him and the women; he craved for them. With a failure in many aspects of life he grew up prone to frustration and dissipation without any particular aim in life until he came in contact with Abdul Bari Alig, the editor of Mussavat. Bari introduced him to the world of literature; short stories of Guy de Maupassant, victor Hugo, Oscar Wilde and others, and encouraged him to write. With all interest as a neophyte he began writing articles and translating the masters in Urdu. Eventually he became a master story teller in Urdu using materials from his own life, colouring them with all his characteristics, so much so that his works came to be marked as Manto's oeuvre; exceptionally his, making him immortal writer of short stories in a short life span of less than 43 years.

His works were carried the image of his life; rich with golden harvest of experiences gathered out of his mixing with people in the lower rungs of society. His short stories became the basis of his livelihood. Before delving into his stories it is worthwhile to peep into his life which was reflected in his stories.

Originally Kashmiri, Hasans settled in Lahore. His grandfather was a pashmina (a special type of woolen) dealer. Later they shifted to Amritsar in Punjab. Hasan's father, Maulvi Ghulam Hasan was a barrister and retired as a sub-judge from Samrala, near Ludhiana. He married twice and had 12 children. All his children were settled, sons being foreign degree holding barristers. But Manto, a son of his second wife, was very unmindful and inattentive to studies; cleared matriculation in three chances with poor marks. His further studies neither at Hindu Mahasabha nor at Aligarh University was successful. He was very poor in his mother tongue, Urdu, in which he prospered as a writer. Critics say that his Urdu was very colloquial, never classical or ornamental unlike other contemporary writers like Ismat Chugtai. Both shared the same charges for obscenity. 
His family was strictly orthodox and religious Muslims, disliking film, theatre, music and such things of plebian entertainment but he was not. They were deeply faithful but he was not concerned about religious faith. He liked a hedonistic life with habits of drinking, gambling and other habits. His father was a sharp tongued person who severely dealt with Manto who he wished to be a barrister in keeping with the family tradition. Saadat Hasan dreaded his father and was intimate only with his mother in the family. Perhaps the most offensive was his life style with inclinations to write fictions and producing or helping to produce films. He liked such art forms. Naturally he became isolated and to some extent out of frustration plunged in the life style of his choice. Poverty naturally gave him company from the beginning to the end of his life for he did not know anything other than writing or trying his hands in the film industry.

Isolated from family his daily requirement was drink and married as he was with three loving daughters besides a wife, he required minimum supply of money to keep him going. Pressed as he was by circumstances and incorrigible habits, he had to earn money by any means. Finding a chance to edit an Urdu film magazine, titled "Mussavvir", he came to Bombay sometime in 1935 and joined it in 1936. He instantly loved the city. Here he mixed up with all sorts of people; people of the lower ranks like pimp and prostitute, washerman and tongawala. He also mixed with some middle class people and sometimes with some higher class of people like a film star, Ashok Kumar. They gave company to each other for some time. For one and a half years he tried his luck with All India Radio in New Delhi, earning regular salary which he liked but due to big differences with the boss he had to give up the job.

He was secular by nature. He wrote his first short story, "Tamasha" as a reaction to the Jalianwala Bagh massacre. Manto was worried at the turn of the situation due to rivalry between India and Pakistan and at the prodding of his wife Safiya left India for Pakistan and settled in his familiar town, Lahore, in 1948. 
Most of his colleagues did not know why he left for Pakistan as he was not at all involved in politics or partition imbroglio which was a big shock in his life but it helped him create the most poignant stories with an inherent weakness for woman which made him not only famous but immortal. Living hand to mouth he sometimes wrote the same story differently and got them published against payment. In film industry, in script writing particularly, he sometimes earned good amount which he lavishly spent in drinks and entertainment but such chances were rare in Pakistan. He became poorer. The partition between two communities in Indian subcontinent and the horrible result of it threw him into insanity for some time as poverty had induced tuberculosis earlier in his youth. In a tragic life "His last wish, literally made with his dying breath, was for a drink of whisky." (Jalil Introduction 10) He died of cirrhosis of the lever due to excessive drink on 18 January 1955.

\section{In the Heart of his Short Stories}

He wrote large numbers of stories as are scattered in 22 volumes in spite of some repetitions. Of the stories the best known are his partition stories. And here some of them are: "Khol Do", "Reunion” or "Open it"- the same story- (Cowasjee and Duggal 154 also In Jalil Introduction) is the story of a family migrating from India to Pakistan during the partition of India. Beginning his journey from India with his wife and daughter, Sirajuddin reached the railway platform of Mughalpura, Lahore, after the dreadful journey from Amritsar when hundreds were killed, injured and lost and the rest of women were raped. He just lay down for hours on the platform of Mughalpura. He remembered his wife with ripped open stomach; dying.

He found no trace of his beloved daughter. On his earnest request some volunteer boys after a few days found a female body, half dead, near the railway track. This was Sakina, the daughter 
of Sirajuddin. She was taken to a hospital. Let us see the last scene of the story for a better insight.

"Sirajuddin stood still outside the hospital beside a wooden pole. Then slowly, he went in. There was no one in the dark room, just a stretcher with a body on it. Sirajuddin approached, taking small steps. Suddenly, the room lit up. Sirajuddin saw a mole on the pale face of the body, and cried, 'Sakina!'

"The doctor who had turned on the lights said to Sirajuddin, 'What is it?'

“Sirajuddin managed only to say, 'Sir, I'm... sir, I'm... I'm her father.'

The doctor looked at the body on the stretcher. He checked its pulse and said to Sirajuddin, “"The window, open it!"

"At the sound of the words, Sakina's corpse moved. Her dead hands undid her salwar and lowered it. Old Sirajuddin cried with happiness, 'She's alive, my daughter's alive!

"The doctor was drenched from head to toe in sweat." 1

This famous story by Manto has been compared with Mahasweta Devi's "Draupadi”. Both are rape stories belonging to different circumstances and different time; they happened in two partitioned parts of the same country. Disrobing of female bodies has dramatic effect in both the stories. While disrobing herself by Dopdi in "Draupadi" denotes immense courage and power of women, the mechanical opening of her shalwar by Sakina in Manto's story signify her weak submissiveness in the face of immense torture by men. Sakina's horrible experience stripped her of all shame and honour of womanhood. The youthful innocence and conservative, hesitant mannerisms that Sakina expressed in the initial scene of the story is replaced by a shocking submissiveness. Like a robot she is ready to obey the order of opening her dress any number of times. It represents an example of utmost humiliation and degradation of woman.

Manto has shown utmost courage in unveiling the horror of the story, even selfcritically, as the scene of action was in Pakistan and the victim was Muslim, as he was 
unconcerned here as to who are the perpetrators of the crime and who is the victim. Such things happened on both sides of the border. Here the question before him was of humanity, of womanhood. It brings to our mind a famous line from Kaji Nazrul Islam's poetry, "Hindu or Muslim, Who's asking? / Tell them that drowning is man /The son of my mother." (Kandari Hushiar or Helsman be alert) While Manto had shown utmost courage in bringing out the true and immediate result of partition, the hollowness and nakedness of the policy and activities of the coloniser and the governments. The government in his country brought charges of pornography against him signifying the irony of fate of the nations and governments.

"Kali Shalwar" /"Black Shalwar" (Jalil Introduction) was another arrow shot at the partition supporters. "One Minute Story" tells of another inhuman behavior of religionist beasts. Two men bought a girl from the chaotic market and used her for satisfying their lust but the next morning they learnt that the girl belonged to their very religion. Hoodwinked, they planned to claim the money back from the seller as they would have enjoyed more from a girl if she belonged to their rival religion. Criminals stain the religions too but Manto has not named any religion here.

"Toba Tek Singh" (Cowasjee and Duggal 145) is a story which tells about the inefficacy and ill effect of partition which turns sane persons to lunatics. A couple of years after partition both India and Pakistan decide to exchange mental patients belonging to their countries but living in the other. The patients of one hospital fail to understand how a place which belonged to Hindusthan could now fall inside Pakistan. Mad Bishen Singh refuses to go to Hindusthan and he stubbornly stands in No Man's Land between the two countries all through the night and just before the morning ejaculates a cry, falling dead.

Many more partition stories are found in his collections. One such is "Sharifan". It is the story of violent reaction, almost inhuman rage and revenge of Qasim when he and his family 
are attacked by enemies. He finds himself injured with a bullet, finds his wife dead and discovers his daughter, Sharifan, naked and dead.

"Barely a yard away, lay the dead body of a young girl-naked, absolutely naked. Fair complexioned, taut and nubile, the small pert breasts were raised towards the ceiling." (Jalil 42) It is not written who attacked and how. It is understood that the rival religionists attacked them.

Qasim went out with an axe, "Axe in hand he swept through the deserted bazaar like a stream of molten lava." (Jalil 43) He was almost blind in murderous rage and killed three Sikhs. Then he found the loud shout, "Kill them! Kill them!" (Jalil 43) but found none. He ran through the deserted road spewing the most awful "Most mother-sister profanities that he could think of and then, "Began to scream daughter-related obscenities". (Jalil 44) Like a mad man he knocked at a closed door shouting all profanities. It was opened after sometime by the lonely resident at that time who was a girl of 14 or 15 years.

“Qasim clenched his teeth and then thundered, 'Who are you?'

“The girl ran her tongue over dry lips and answered, 'A Hindu.' (Jalil 44)

He threw himself upon her, tore her dresses to pieces and throttling, massacred her. Then he tried to cover her with a blanket when her father returned with a sword in hand. He recognized Qasim and asked what he had been doing there. Qasim pointed at the dead body and uttered in a hollow voice, 'Sharifan'. As the man looked at the mangled dead body of his daughter the sword fell from his hand and he ran out of the house in wobbly legs muttering, 'Bimla . . Bimla ...'(Jalil 45)

So Bimla was killed for Sharifan.

Though Manto has eyes for details, sometimes he fails as we can see in the description of Sharifan's dead body. It could not be so taut, breasts raised to the ceiling as she was dead, must be after sufficient torture. Manto was fascinated by naked bodies; in anyway, a weakness 
indeed. And there arise another question, can an innocent girl come out and utter before the demon of a man like Qasim in answer to his question, who are you, the only word, 'Hindu'? Is it as if the girl in such riotous day was ready for a communal self-sacrifice? Isn't it stretching the imagination too much?

"Bismillah" (Jalil 1) is the story of an eponymous Hindu woman who during the partition riots was possessed by a Zaheer who, showing her as his beloved wife engaged her as prostitute and earned at her cost. Saeed, a friend of Zaheer, began to visit her daily and enjoy voyeuristic pleasure by mixing with her during his friend's absence to learn finally of the fact of her life and of a different kind of deception and betrayal of faith by his friend. Bismillah was a victim of their lust and deception.

"By God" (Jalil 94) is a spectacular partition story told in a narrative fashion interspersed by dialogues. Here the writer uttered his shock of seeing large numbers of women with swollen and distended bellies, "What would happen to these bellies? Who is the owner of that which lies stuffed in these bellies-India or Pakistan? And what of the nine months of labour? Who would pay the wages- India or Pakistan?" (Jalil 95)

Here ("By God") a Muslim mother walking and living along the border with only one hope that her beautiful daughter could never be killed by any human being. She searched and searched for her growing older and emaciated day by day, tending towards insanity. She never agreed that her daughter was killed. But when her really beautiful daughter was seen passing with a beautiful Sikh youth, pausing for a moment to look at her mother as suggested by the Sikh but deciding in an instant to proceed without tarrying any more, she felt the real loss of her daughter. Her daughter was living but denied or ignored her existence in the face of her youthful exuberance, signifying the death of a daughter to an ever affectionate mother. As the protagonist of the story tried again to convince her that her daughter had been killed, she believed and fell dead then and there. This is a very sad, dramatic and highly poignant story. 
Saadat Hasan Manto is an artist per excellence with all his strength and weakness. With staccato notes he uses refrains and creates poetic charm in his stories. He loves erotic side of life and adored it in his stories. But he was moral and responsible human being, a serious writer. His concern for women of all societies, particularly the fallen and tortured women is exceptional and he never becomes partial in his dealing with woman. He was above religion when considering the crime against them by the vile and the pervert. One may write more essays on his stories with the gift of varieties. One may analyse elaborately many of his short stories which were seldom very big. Most of his stories have standard length, which he writes with a sense of proportion, with significant beginning and end. In spite of all pitfalls for which he paid for with his life, the storyteller and artiste Saadat Hasan Manto's greatest success was that he was true to his profession and was very successful at the acme of his creation.

\section{The Creative Process}

The short duration of his life many be compared to the lives of such genius poets like Arthur Raimbaud, John Keats, P. B. Shelley, Taru Dutt and Sukanta Bhattacharya. Manto's was a case of wearing out his life, consumed by erotic passion and literary creation necessitated by creative urge and longing to live recklessly. The Mother of Pondicherry observed during the artistic and creative period of her life in France as painter that artists often lead an unbalanced life between art and ordinary life, often living a life lower than ordinary people. For all reasons and beyond reasons, Saadat Hasan Manto became a prolific writer in a crowded life of turmoil and terrible suffering of less than 43 years, producing five collections of Radio Plays (seven according to some), 22 collections of short stories, one novel, two collections of sketches and three collections of essays besides some film scripts. Consumed between the creative urge and passion for sensuous life he emerged as one of the most humane writers championing the cause 
of women who were the innocent victims of partition of the country while the leaders enjoyed their leadership and power.

Though he wrote some biographical features and political satires he became famous and immortal for his short stories. He wrote short stories pertaining to other times than partition and of different themes but those belonging to Partition of India were most poignant, haunting and successful creatively. It seems as if someone squeezed out of his compressed life between passion and creation some superb stories that emerged out of the tremendous turmoil in a particular junction of human life. Saadat Hasan Manto was the instrument of such creation.

Partition was such a horror to him that he wrote, "When I sat down to write I found my mind in a confused state. However much I tried, I could not separate India from Pakistan and Pakistan from India." 2

Most daring and adventurist, Manto plunged in the most intimate and sexy areas of life, man- woman's corporeal stories, which he wrote with minute details. Almost all critics admitted his weakness and strength of bringing out the hidden dark areas, mostly in the lower regions of human life. Rakshanda Jalil, the editor of one of his collection of short stories, has written in her introduction, "Although Manto wrote obsessively about sex, and the kind which happened between those who were equally obsessed with it, he often treated sex as part of life's essential pangs-hunger, sleep and love.” (Jalil Introduction 13)

He was charged for voyeurism, sensationalism and obscenity and cases were framed against him. Haunted by society and the underworld, by the division of the country and in acute financial troubles, he braved everything amidst creation and dissipation, living the life of a hedonist and artist and at the same time that of a poverty stricken person.

In spite of all materials in hand none other than Manto could produce the stories that he did. When to begin, how suddenly to jump into the situation and drag the readers into it creating all interest and suspense, when to end successfully leaving the reader with a pungent or sometimes 
a luscious taste for the materials used, were well known to him; the combined effect of all this was the art of his writing stories. All this makes the crafts of writing short stories and Manto was a specialist in it, in full control of the creative process. With pride he wrote an epitaph for his grave, a year before his death, "Here (Manto) lies buried-and buried in his breast are all the secrets of the art of story-telling." (Jalil Introduction 7) Defying all charges he dared to write, "I am no sensationalist. Why would I want to take the clothes off a society, civilization and culture that is, in any case, naked? Yes, it is true I make no attempt to dress it-because it is not my job; that is a dressmaker's job. People say I write with a black pen, but I never write on a black board with a black chalk. I always use a white chalk so that the blackness of the board is clearly visible." (Jalil Introduction 16) True it is that almost in every story he used the word naked as he found his characters naked. Whether he liked it or not, it seems that he had a knack for it.

\section{Notes}

Saadat Hasan Manto's Selected Stories. Translated by Aatish Taseer. (Random House India; Www.randomhouse.co.in )

“Timeless appeal” by Asif Noorani. The Hindu dated 20 May 2012 


\section{References}

Jalil Rakshanda. Naked Voices Stories and Sketches. New Delhi: Roli Books Pvt. Ltd. (IndiaInk). 2008. Hard bound

Orphans of the Storm. Editeed by Saros Cowasjee and K. S. Duggal. New Delhi: UBS

Publishers’ Distributors. 1995. Paperback

The Vikas Book of Modern Indian Love Stories. Edited by Pritish Nandy. New Delhi: Vikas Publishing House Pvt. Ltd. 1979. Hard bound

Devi Mahasweta. Breast Stories. Calcutta: Seagull. 1998. Second Print. Paperback. (Draupadi 19) 